\title{
How To Raise Social Capital: An Experiential Exercise
}

Peter H. Hackbert, (Email: phackbert@sierranavada.edu), Sierra Nevada College

\begin{abstract}
Social capital is a critical aspect for launching a new venture. In the popular press and entrepreneurial education classrooms, "develop your network" is one of the most common pieces of entrepreneurial advice. Developing social capital is a crucial entrepreneurial competence. Three common questions are: What is the idea of a network of relationships as social capital? What are the dimensions of effective networks? How can nascent entrepreneurs develop strategies and abilities for building a valuable network? At Sierra Nevada College, the Sharon M. Croom Center for Entrepreneurial Leadership Teaching Fellows have designed the "Entrepreneur Network Experiential Exercise" to get students into thinking about these social capital resource questions and taking action in developing social networks .
\end{abstract}

\section{INTRODUCTION}

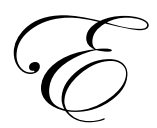

ntrepreneurs require information, capital, skills, and labor to start new venture activities. While they hold some of these resources themselves, they often complement their resources by accessing their contacts (Aldrich \& Zimmer, 1986; Aldrich et al., 1991; Cooper, Folta, \& Woo, 1995; Hansen, 1995). The resource contacts that lead to successful outcomes are their social capital, which become a key component of entrepreneurial networks (Burt, 1992). Gabbay \& Leenders (1999) define social capital as the set of tangible or virtual resources that accrue to actors through the social structure, facilitating the attainment of the actors' goals (Lin, 1999; Portes, 1999). They include contacts that help them get things done. These are people the entrepreneur knows, or who are known by others that the entrepreneur knows. When the entrepreneurs' contacts contribute to their entrepreneurial goals, these social contacts are their social capital (Burt, 1992).

Social capital - the resource available from one's networking of relationships - is critical to the development of new venture opportunities. In the popular press and entrepreneurial education classrooms, "develop your network" is one of the most common pieces of entrepreneurial advice but until now, scant attention has been paid to the impact of entrepreneurial networks and social capital by both academic researchers and entrepreneurship educators. Often professors say that one needs a strong network of relationships to be successful, but we rarely stop to consider what that means. What characterizes a useful network? How does one develop a more effective network of relationships?

Social capital is a critical aspect for small businesses (Spence, L.J., Schmidpeter, R., and A. Habisch (2003). Social capital plays a more important role in economic transaction when information with respect to qualities of professionals is imperfect (Pennings and Lee, 1998). Entrepreneurs who possess increased social capital are also more likely to receive outside funding (Baron and Markham, 2003). Spence (2004) highlights the importance of informal relationships, trust, and solidarity for small business development. Increased social capital has been found to be associated with enhanced access to information and increased cooperation and trust from others. Firms that increase their social capital benefit in forming strategic alliances both to decrease the costs through alliance partners and to create new economic opportunities.

Granovetter (1985) reports that social networks have increasingly been adopted as a medium for understanding entrepreneurial behavior both in start-up phase of new enterprises as well in developing and growing new ventures. A firm's ability to attract and retain clients depends not only on its competence to produce high-quality service, but also on its connections to potential clients (Maister, 1993; Smigel, 1969). Empirical research found that 
social capital is positively related to firm performance (Baker, 1994), product innovation (Tsai and Ghoshal, 1998), and industry-wide network formation (Walker et al., 1997). Thus entrepreneurs that engage in social activities and wisely manage social relations save significant transaction costs in the search for critical information and provide unique economic opportunities.

To date, a limited number of studies have linked social networking to growth aspiration of nascent entrepreneurs. One of the most common misconceptions among untried and nascent entrepreneurs is that they have to have all the resources in place, especially the money, to succeed in a venture. Thinking money first is a big mistake. Money follows high-potential opportunities conceived of and led by a strong entrepreneurial team. Investors have bemoaned for years the fact that there is too much money chasing too few deals. In other words, there is a shortage of quality entrepreneurs and opportunities, not money. Successful entrepreneurs devise ingeniously creative and stingy strategies to marshal and gain control of resources. Investors and successful entrepreneurs often say that one of the worst things that can happen to an entrepreneur to have too much money too early.

There is little dispute today that the entrepreneurial team is a key ingredient in high-potential ventures. Investors are captivated "by the creative brilliance of a company's head entrepreneur: a Mitch Kapor, a Steve Jobs, a Pierre Omidyar, a Jerry Yang, ... and bet on the superb track records of the management team working as a group" (Bygrave and Timmons, 1992). Venture capitalist John Doerr reaffirms the father of American venture capital General George Doriot's dictum: I prefer a grade "A" entrepreneur and team with a grade "B" idea to a grade " $B$ " team and a grade "A" idea. Doerr stated, "In the world today, there's plenty of venture capital. What's in short supply is great team. The nascent entrepreneur's biggest challenge will be building a great team (Doerr, 1997). The investor Arthur Root articulated the importance of the team over a decade ago, putting it this way: "If you can find good people, they can always change the product. Nearly every mistake I've made had been when I picked the wrong people, not the wrong idea (Root, 1987). Research indicates that ventures with more than 20 employees and $\$ 2$ million to $\$ 3$ million in sales are much more likely to survive and prosper. In the vast majority of cases, it is very difficult to grow beyond this point without a team of two or more key contributors.

A powerful way to understand and marshal the social capital resources required to exploit the opportunitydriven entrepreneurial process is through networking. The broader one's network is, the more knowledge one can tap. This may take the form of adding people to the entrepreneurial team or building what is called a virtual team and social capital. As entrepreneurs require external financing, often the money comes from family members, friends, and angels. These individuals in the entrepreneur's network are shown to be keys to success. The larger the social capital, the greater the odds are that new venture founders can tap into the right knowledge source. To that end, entrepreneurs should have the goal of meeting five or more new people a week. Furthermore, nascent entrepreneurs need to maintain contact with the network on both a personal and professional basis. People within the network are more apt to respond quickly when founders contact them. On a professional level, it is important for entrepreneurs to send a periodic newsletter detailing the state of their progress to all current and potential stakeholders. This keeps entrepreneurial efforts fresh in the minds of the social network participants and often spurs people to act on the behalf of the new venture. These social capital resources might connect the entrepreneurial team members with an investor or customer without directly soliciting their help. As entrepreneurial teams start the new venture planning process, educators and practiticioners recommend they talk with as many people as possible and keep the network informed of the new venture progress and milestone accomplishments.

At Sierra Nevada College, we have designed the "Entrepreneur Network Experiential Exercise" to get students into thinking about social capital resource questions. The exercise provides them with an opportunity to diagnose their own network of relationships as they identify strengths, preferred approaches, and gaps. Completing this exercise serves as a platform for class discussion. Collecting students' network data before class allows faculty to share their collective results as the class discusses the dimensions of effective networks, the idea of a network of relationship as social capital, and strategies for building a valuable network. 


\section{LEARNING OBJECTIVES}

1. To provide an opportunity to diagnose the network needs of their current or future position, to identify gaps between those needs and their current network.

2. To provide students an opportunity to analyze their preferred and their current network.

3. To help students understand how one-to-one relationships are affected by one's network of relationships: The overall pattern of the relationship affects the power balance of any one relationship.

4. To consider strategies for building a useful network that will help one to accomplish tasks, develop career relationships and future opportunities.

\section{ASSIGNMENT}

Students should complete the Entrepreneurial Network Experiential Exercise and turn in the last page at least several days prior to the day on which the exercise will be discussed. In addition to the Entrepreneurial Network Experiential Exercise, I assign a "case study" to be read only after completing the exercise, which provides a framework for network diagnosis and strategies for building and managing a network. I also assign Tom Peter's "The Power of Wow," which describes very practical network-building and management tactics.

\section{ASSIGNMENT QUESTIONS}

1. What did you find most interesting or surprising in filling out your network experiential exercise?

2. What patterns, if any, characterize your network?

3. What are the primary advantages and disadvantages of your network? How well aligned is it with your career objectives? In what ways can your network be improved?

4. How consciously do you work to develop and maintain a useful network?

5. Turn in page 7 prior to class discussion. 


\section{Entrepreneurial Network Information}

Peter H. Hackbert, (Email: phackbert@ sierranavada.edu), Sierra Nevada College

This exercise is designed to help you identify patterns in your approach to developing networks of relationships. Your "network" refers to the set of relationships that help you advance professionally, get things done, and more generally, develop personally and professionally.

\section{DIRECTIONS}

Follow the instructions for Steps 1 through 5. The information you turn in will be anonymous, so please insert your student ID number (last four digits of your social security number).

\section{Please DO NOT turn to page 6 (Step 5) until you have completed pages 2 to 4 of this exercise.}

\section{STEP 1: LIST YOUR NETWORK CONTACTS}

In answering the following questions, you may list people from ANY context. It is not necessary to limit yourself to fellow college students or co-workers from previous jobs. People with whom you have more than one kind of relationship can be listed more than once. In the blanks that follow each question, please list their names or initials. You may list up to six names per question. You may list as few as you wish or leave a question blank if no one comes to mind.

A. Important Work For Academic Matters: If you look back over the last year, who are the people with whom you have discussed important work or academic matters? This may have been for clarifying new ideas for an important new venture or project, getting support or cooperation for your initiatives, evaluating opportunities or any other matters of importance to you.

B. Job Search: What people have been most helpful and useful in your job search so far? Consider people who have provided leads, made introductions, offered advice in your career and job decision-making, or other possibilities.

C. Friends: List your closest friends. Consider those with whom you most like to spend your free time or with whom you would be most likely to discuss a personal dilemma. 
D. Professional Development: During your undergraduate school years, list those people who have contributed most significantly to your professional development during the past year. You need not limit yourself to members of the college community.

\section{STEP 2: CONSOLIDATE YOUR LIST}

Consolidate the names listed in the four questions of Step 1 onto the Entrepreneurial Network Grid on page 7. No person should be listed twice.

\section{STEPS 3: DESCRIBE THE CLOSENESS OF THE RELATIONSHIP}

For each person listed on the network grid, indicate the closeness of your relationship with them by placing an " $\mathrm{X}$ " on a continuum from "very close" to "close" and "not very close" to "distant." Very close relationships are those characterized by high degrees of liking, trust, and mutual commitment. Distant relationships are characterized by not knowing the person very well, or by having very little liking, trust, and mutual commitment (i.e., problematic relationships). For an example of how to complete this step, see the Sample Entrepreneurial Network Grid on page 8, entitled "Colin's Network".

\section{STEP 4: COMPUTE THE DENSITY OF YOUR NETWORK}

Density refers to the extent to which the people in your network know each other. Using the grid on the next page, indicate who in your network know each other by placing a checkmark in the cells corresponding to each acquainted pair. Leave a cell blank if the pair do not know each other or if you do not know whether they know each other.

Start with person 1, for example Lisa in the Sample Entrepreneurial Network Grid for Colin, on page 8. Going across the gird, Lisa knows Jack (2), and Jeff (3) and Samantha (8) but no one else in Colin's Network; Go on to person 2, Jack. Jack knows Rick (5) Linda (6), Samantha (8) and David (10). Go on to person 3, and so forth. (Note: Do not place any checkmarks in the shaded area. If person 1 knows person 2, then person 2 knows person 1. Once you have finished check marking who knows who, compute the density of your network through the following steps:

A. Total number of people in your network. To follow our example, Colin's $\mathrm{N}=10$

$\mathrm{N}=$

B. Maximum Density (i.e., if everyone in your network knew each other). Colin's maximum density is $(10 * 9) \div 2=45$. $[\mathrm{N} *(\mathrm{~N}-1)] \div 2=45$

$\mathrm{M}=$

C. Total number of checkmarks on your network grid (i.e., the number of relationships among people in your network).

$\mathrm{C}=$

D. Density of Your Entrepreneurial Network. Colin's $\mathrm{D}=19 \div 45=.42 . \mathrm{C} \div \mathrm{M}=\mathrm{D}$

$\mathrm{D}=$ 
When you have completed Steps 2,3 and 4, go to page 6 and complete Step 5

\section{STEP 5: SUMMARIZE THE ENTREPRENEURIAL NETWORK INFORMATION}

Complete the sections below, and hand in this page and only this page. To maintain anonymity, please DO NOT write your name on this sheet. Insert the last four digits of your social security number.

Individual Information (Circle applicable)
A. Last job before College
Large
Corporation
Small Firm
Sole
Other
B. Gender
Male
Entrepreneurial
Proprietor
C. Nationality (by region)
US and Canada
Central America and Mexico
Latin America
Europe
Africa and Middle East
Australia \& New Zealand
Asia

\section{Network Information}

A. Total number of people listed on the Entrepreneurial Network Grid (from Step 2)

B. Number of "Very Close" relationships listed on the Entrepreneurial Network Grid (from Step 3)

C. Density of your Entrepreneurial Network (D from Step 4)

D. Look over your Entrepreneurial Network Grid and determine the number of people who are:

1. From the same industry background

2. From the same company (pre-college)

3. Fellow undergraduate college students

4. Liberal arts faculty

5. More senior than you, for example, faculty or supervisors

6. At your level, in school or at work

7. More junior that you, in age or organizational position

8. The same gender as you

9. The same racial or ethnic group as you

10. The same nationality (by region) as you 


\section{Entrepreneurial Network Grid}

\begin{tabular}{|c|c|c|c|}
\hline \multirow[t]{2}{*}{$\begin{array}{c}\text { Step 3: } \\
\text { Very } \\
\text { Close }\end{array}$} & \multicolumn{3}{|c|}{$\begin{array}{r}\text { Notationships } \\
\text { very }\end{array}$} \\
\hline & Close & Close & Distant \\
\hline & & & \\
\hline & & & \\
\hline & & & \\
\hline & & & \\
\hline & & & \\
\hline & & & \\
\hline & & & \\
\hline & & & \\
\hline & & & \\
\hline & & & \\
\hline & & & \\
\hline & & & \\
\hline & & & \\
\hline & & & \\
\hline & & & \\
\hline & & & \\
\hline & & & \\
\hline & & & \\
\hline & & & \\
\hline & & & \\
\hline & & & \\
\hline & & & \\
\hline & & & \\
\hline & & & \\
\hline
\end{tabular}

Step 2: List Names $\quad$ Step 4: Density of Network

$\begin{array}{lllllllllllllllllllllll}2 & 3 & 4 & 5 & 6 & 7 & 8 & 9 & 10 & 11 & 12 & 13 & 14 & 15 & 16 & 17 & 18 & 19 & 20 & 21 & 22 & 23 & 24\end{array}$

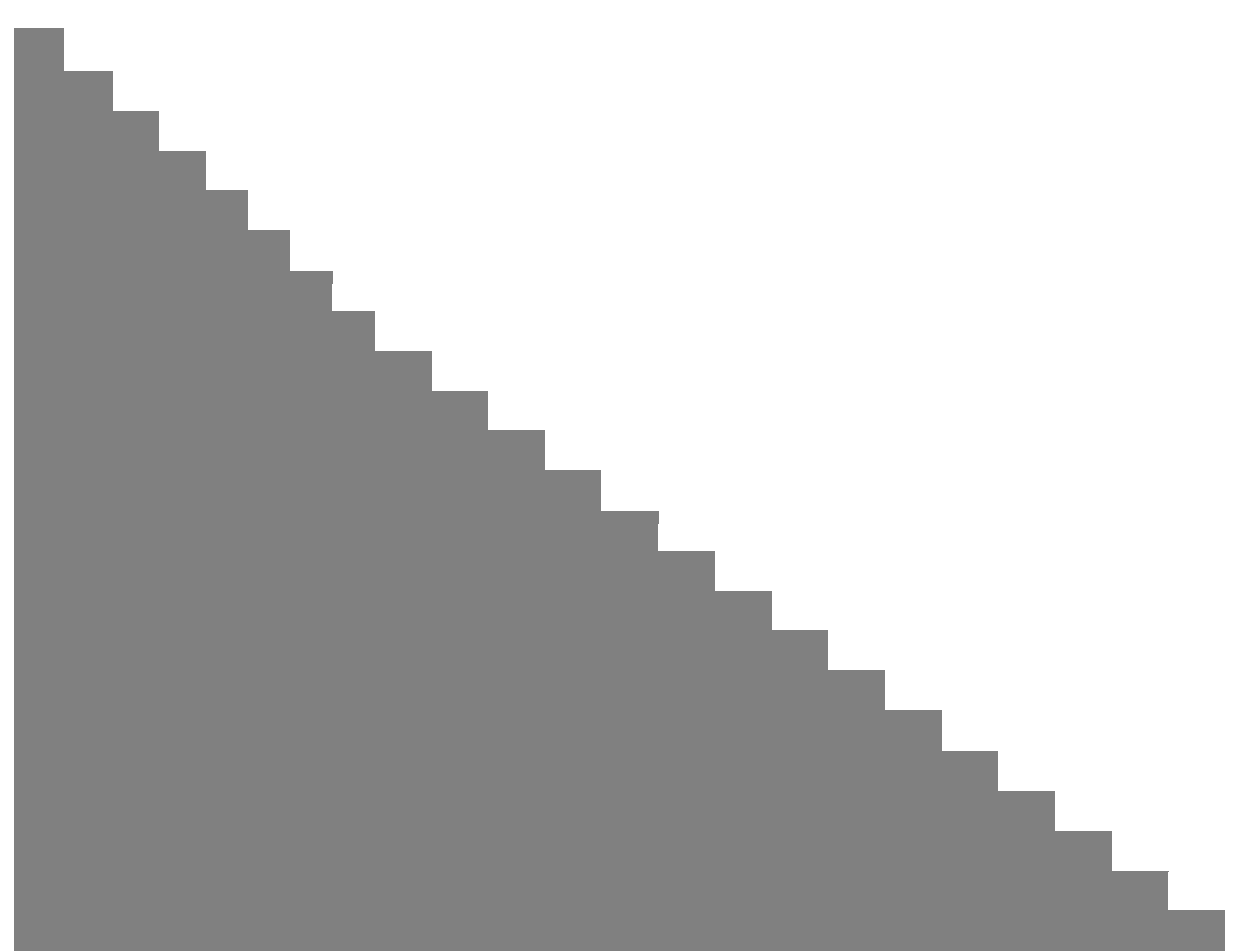


Sample Entrepreneurial Network Grid: Colin's Network

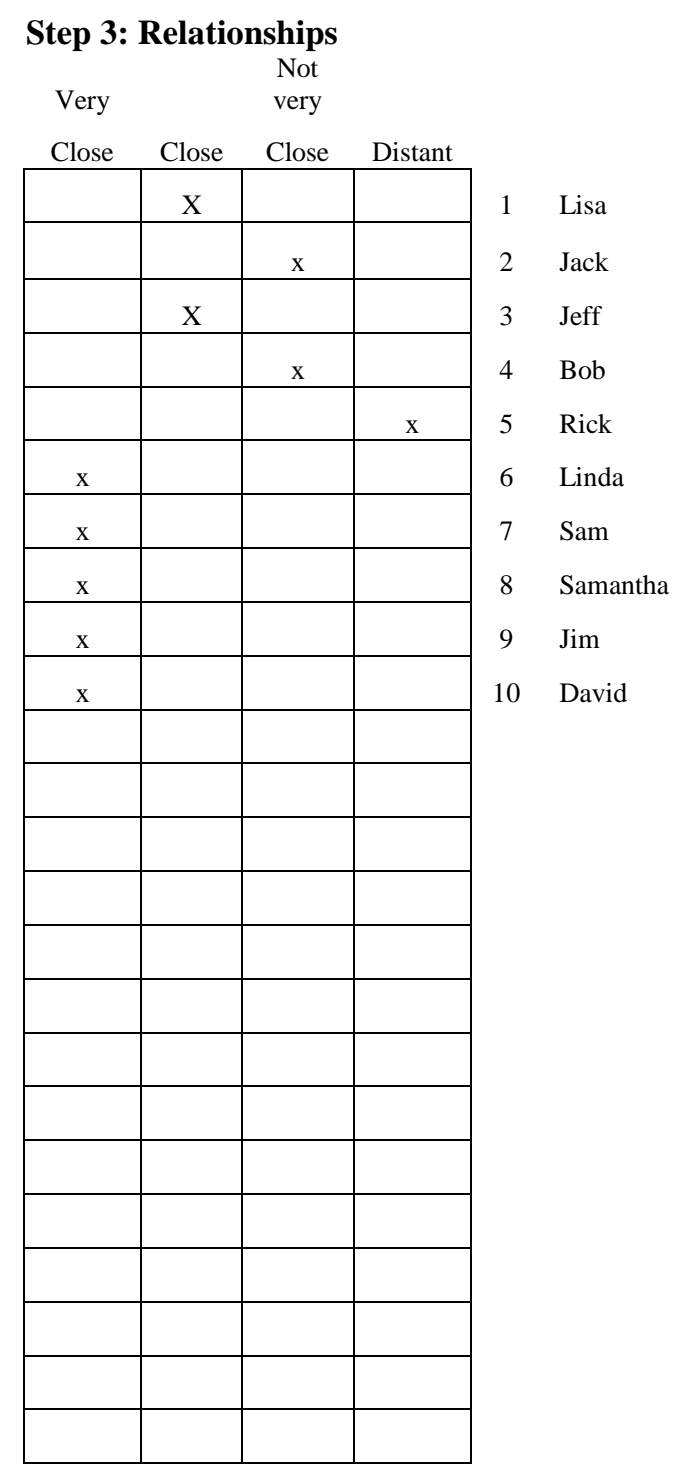

Step 2: List Names

Step 4: Density of Network

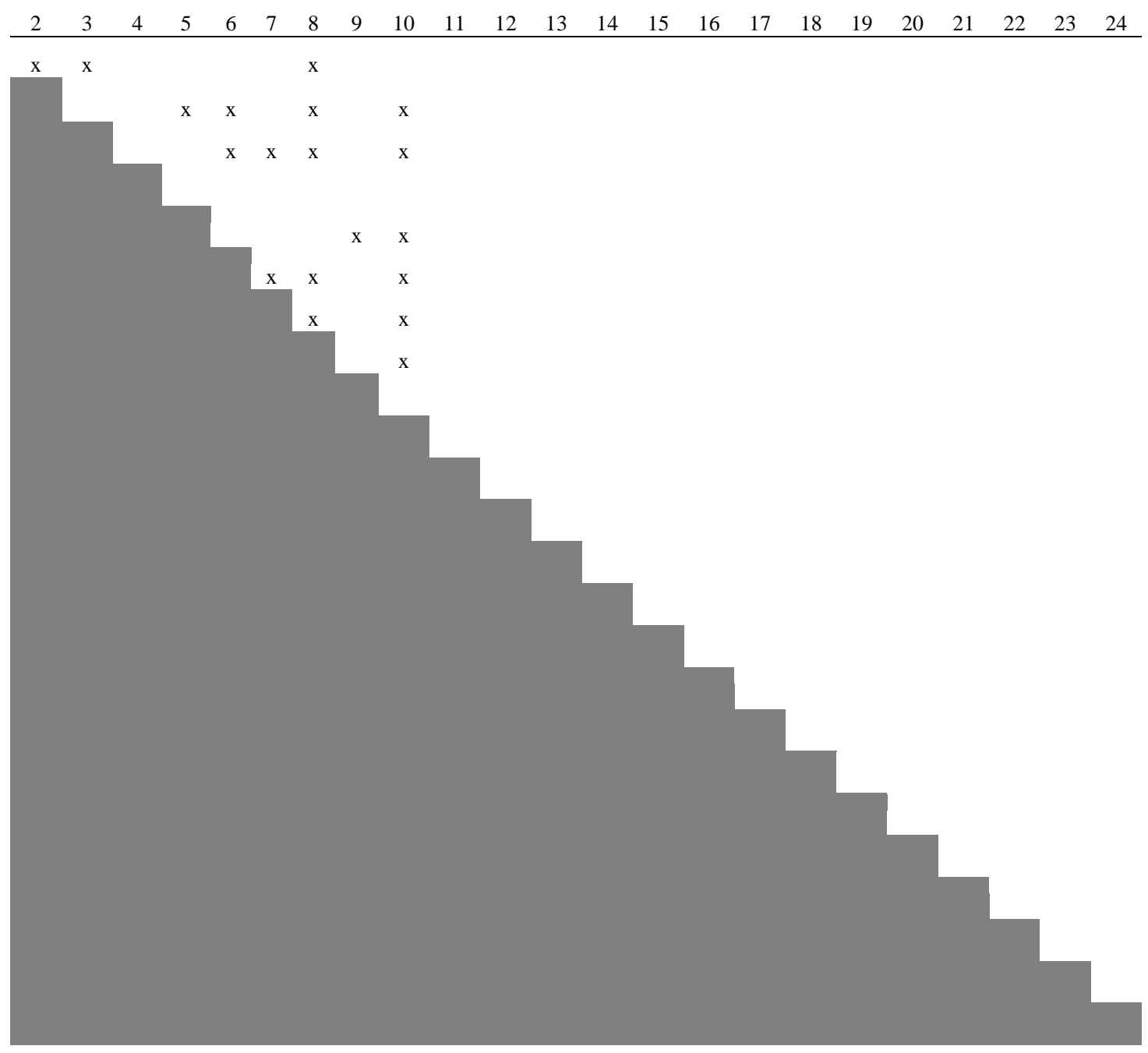


